\title{
A FORÇA DO DESTINO: UMA PARÓDIA ORQUESTRADA COM MAESTRIA POR NÉLIDA PIÑON
}

\author{
Neiva Kampff Garcia \\ Mestranda em Literatura - UFRGS
}

\begin{abstract}
RESUMO
As presentes considerações são uma leitura analítica de $A$ Força do Destino, de Nélida Piñon, obra publicada em 1978, cuja temática dialoga com a ópera homônima, composta em 1861, por Guiseppe Verdi. Nossa proposta é de um olhar espectador diante da apresentação de uma paródia proposta em prosa, que desfila diante de nós teatral e operisticamente, enquanto nos permite conhecer a maestria de uma regente que, utilizando a batuta da língua, nos conduz pelo universo da imaginação.
\end{abstract}

PALAVRAS-CHAVE

A Força do Destino; Nélida Piñon; paródia.

THE FORCE OF DESTINY: A PARODY ORCHESTRATED WITH MASTERY BY NÉLIDA PIÑON

\begin{abstract}
The present work is an analytic reading of the novel The Force of Destiny, by Nélida Piñon, which was published in 1978 an has a theme that dialogues with the opera of same title composed in 1861 by Giuseppe Verdi. My proposal consists in assuming a spectators' glance towards the presentation of this parody that is written in prose but that parades before us theatre and operatically, allowing us to know the mastery of a conductor that uses the language baton to lead us through the universe of imagination.
\end{abstract}

\section{KEY-WORDS}

The Force of Destiny; Nélida Piñon; parody. 
A proposta inicial de nossa leitura é acompanhar, no romance $A$ Força do Destino, a paródia estabelecida por Nélida Piñon e o seu compor narrativo, enquanto autora que se assume como parte dos elementos textuais e contextuais da obra. É dessa escritura que nos falam as diversas vozes, que ora se apresentam como narradores, ora como personagens, igualmente como "autores", instigando o leitor a "assumir" partes dessa elaboração, convidando-o a fazer parte do processo criativo. Alheia ao fazer literário tradicional, a autora rompe com as normas prescritas, instituindo diferentes relações entre personagem, narrador e autor. Nélida tematiza as técnicas narrativas, cria novas temporalidades textuais - estabelecendo uma cronologia própria - e refaz o percurso da criação literária, numa constante dialética entre construção e desconstrução.

Ao convidar narrador, personagem e leitor a comporem consigo a história que conta e reconta, cria e recria a autora amplia a própria idéia de enredo, abrindo caminho para que outras histórias possam ser agregadas e as personagens possam assumir papéis diversos dos que, originalmente, tiveram no texto da ópera que referencia o romance. A essa elaboração, dinâmica e dialógica, associamos a idéia de uma regência, como se o romance estabelece-se, na arte literária, uma metáfora da arte musical, no caso, a ópera.

Um narrador-personagem denominado Nélida, que é apresentado como cronistaautor, nos conta, por exemplo, sobre a possibilidade de sua relação com os protagonistas:

Exige Álvaro a minha presença porque arrasto um mistério vendido a preço de mercado, e escrever para mim é ato sem preço, pelo qual tenho um valor aviltado? Um pouco mais perto e poderia beijar Álvaro e Leonora. Com saliva e agonia engoliria a representação deste amor. Eles declaram-se amar, dispensam-me para a amargura deste sentimento. Tenho que segui-los como segui a outros durante anos. Pedindo desculpas, proclamando a independência, mas sem prescindir de um sangue com propriedade de envenenar-me ao longo de uma longa dinastia.

Apalpo a vida. Auscultando-lhe a ruidosa exuberância, aprendi que nada exige a minha presença. Unicamente meu corpo narrador afina-se às próprias funções, e tece uma respiração ajustada a um sistema de ar mediante o qual componho notas musicais e espasmos. Apenas o sol é indispensável. Quando escurece e na caverna da terra as carnes humanas imergem no sono com espantosa credulidade. (PIÑON, 1988, p. 18-19)

Num dado momento, esse narrador dialoga com a personagem Dom Álvaro dizendo: “Assim, não te posso socorrer, ou a mim mesma. A tudo escuto pela metade. Narro a tua história com a precariedade da minha condição [...]” (PIÑON, 1988, p. 27). Essa construção transpõe os domínios da narração clássica, dando ao leitor uma impressão de autonomia de todos os que participam da escritura, permitindo-lhe posicionar-se dentro da própria elaboração fíccional. 
É, nesse início de leitura, que se configura uma condição de incerteza sobre quem serão os seres que comporão o enredo. A dialética se instaura em múltiplas interrogações. O sujeito-leitor é instado a analisar as posições de narradores e personagens e as ações que eles protagonizam, como se fosse um coadjuvante do ato narrativo. É uma parceria involuntária que o induz a posicionar-se como um emissor e não mais como um receptor da obra, cabendo a ele preencher com novos sentidos a atualização do enredo, como encontramos no trecho seguinte:

\footnotetext{
Repassemos ligeiramente o texto vencido. Viu o leitor como o cavalo de Álvaro, após a morte do marquês, indicou-lhe a estrada, sem dar tempo ao cavalheiro de perguntar a Leonora se convinha-lhe ainda segui-lo. E que, melindrada com tal procedimento, Curra obrigou a jovem a tomar a direção de Madrid, enquanto Álvaro, atraído pela sonoridade do catalão, encaminhara-se ao condado de Barcelona. A partir destes feitos, teceremos rápidas considerações.

Por exemplo, em que momento Leonora e Álvaro descobriram que a vida em comum lhes seria insuportável, havendo agora um crime entre eles? Em que instante viram-se solitários, poeirentos e sedentos, no meio da estrada, um sem o socorro do outro, sem tempo ao menos de se dizerem adeus? (PIÑON, 1988, p. 48)
}

Torna-se necessário, logo de início, pensar sobre o "como" está sendo contada a história e, ao fazer esse movimento, o leitor assume voluntariamente a sua participação nesse surpreendente fazer literário. Essa forma narrativa viabiliza os sucessivos movimentos, entre a temática original e a atualização, a que escritora recorrerá reiteradamente, através de constantes alternâncias e imbricações. Nélida elabora uma tessitura, no seu enredo, que ultrapassa a linearidade do tempo e a conduta usual no manejo de um texto em elaboração, ao desestruturar a condução progressiva do tema. A imprevisibilidade se confirma gradualmente, por vezes, a cada novo parágrafo, embora haja o conhecimento prévio da história que está sendo contada.

Em determinado trecho do romance, a personagem Leonora assume a narrativa, após um dialogo com o pai, o Marquês de Calatrava, sobre o desenrolar da história cujo enredo original se encontra numa peça espanhola do século XIX. Utilizando uma marcação operística no diálogo do texto atual ela passa, em seqüência, a um questionamento sobre a atuação do narrador-personagem Nélida, cronista, que é responsabilizado pelo esclarecimento do seu fazer literário em andamento:

Criados, corram aqui, eis um ladrão na casa, devemos acorrentá-lo, para os esbirros e a justiça / pai, tudo menos esta desfeita, eu amo Dom Álvaro / então, desgraçadinha, confessas tal amor? / e acaso é amor maldito também, desde quando homem e mulher não gozam de todos os benefícios para se amar à vontade e sem chateação? / não basta serem homem e mulher / ah, se Dona Leonora fosse varão, o senhor melhor aprovaria nosso amor 
homossexual? / pelo menos não estaria à minha vista, eu teria assegurado à sociedade de Sevilha que a honrada casa de Calatrava jamais se uniria a um telhado menos digno com o propósito de ter filhos / pai, acalme-se, como podemos debater problemas tão graves se gritamos todos ao mesmo tempo, já não sei que palavra é de minha lavra, que verbo brotou do seu coração / quem lhe disse que eu quero ouvir, filha, eu exijo tão-somente primorosa vingança, criados seus dorminhocos, onde estão, venham, com as espadas desembainhadas (oh, bainha, onde se guarda a espada e quer dizer vagina, que horror!) / não me obrigue a ser beligerante e profissional, Marquês, quando desejo sim respeitá-lo, aliás, como prova do meu amor por Leonora, e minha estima por vossos cabelos brancos, entrego-vos a pistola, dai-lhe sumiço, estarei assim indefenso. (PIÑON, 1988, p. 28-29)

Oh, meu pai, que dor é esta, cobre-se teu rosto de riscos e mapas. O que houve, de onde veio semelhante estalido? [o Marquês de Calatrava acaba de levar um tiro] Por que tombas ao solo, e agora este filete de sangue, é mesmo sangue, sangue, ah. Poxa Nélida, não estou entendendo nada. Álvaro não me pode responder, veja só que cara ele faz. Vamos, sua cronista mesquinha, o que se passou com meu pai? (PIÑON, 1988, p. 29)

Em outro ato narrativo - como designamos os parágrafos - Nélida, a personagem-cronista, passa a falar a um médico, cuja voz não se manifesta. Esse é um trecho exemplar dos movimentos de atualização temporal dos fatos, postos em trânsito entre os espaços geográficos do enredo atual e do pregresso. A passagem acompanha o processo de criação a que Leonora referia:

Com sua licença, doutor, agora me retiro. Afinal, não sou testemunha de fé, e não tenho firma no cartório da Erasmo Braga. E, depois, inclino-me quase sempre a deturpar o que vi, apenas movida pela ambição de esclarecer os fatos. Que possuísse Dom Álvaro a arma de onde partiu o tiro mortal, não me diz respeito. Minha narrativa é porosa, deve mesmo receber cunhas de madeira em sua matriz, mas nada tão forte que lhe arrisque a autonomia. Ensinou-me a tragédia a exemplaridade do herói, seu encontro marcado com a morte. Quando muito, deixo-me arrastar por lágrimas e pela esperança que purgam a dor, com elas às vezes acende-se a luz da vida.

Já estou atrasada, doutor. Especialmente porque partiram todos a galope. Dom Álvaro, à garupa do animal fiel. O mesmo animal que invadiu o jardim em busca do pobre militar, após Leonora amparar o pai ali a expirar, não sem antes gritar-lhe maldição, maldição, filha ingrata, e Dom Álvaro, desorientado, querendo fugir, e sem saber como. Sim, o cavalo veio a nós, seguramente atraído pelo disparo. Tinha o olhar sensível e algo fatigado. Inclinou-se sobre Dom Álvaro, acariciou-o seguidas vezes, parecia instigá-lo a fuga, não havia outra saída. Ao mesmo tempo, Curra [criada da família] tratava de convencer Leonora a abandonar o local do crime. Queria evitar suspeitas sobre a atuação dos dois nesta tragédia espanhola.

Nada sei da terna ligação de Dom Álvaro e seu cavalo. Pouco conheço de sentimentos assim tão raros. Limito-me a exaurir aquele sentir que se gruda à pele humana, dali afloram urgências e paixões. Pelo que me foi dado ver, imagino o afeto intenso, pois ao animal foi fácil convencer Álvaro a subir-lhe à garupa, acomodar-se com segurança, e desapareceram na noite, esquecidos sim de arrastarem Leonora, com quem o cavalheiro, até há bem pouco tempo, tivera planos de montar um espetáculo chamado futuro. (PIÑON, 1988, p. 31-32) 
A cada novo trecho do romance nos deparamos com novos movimentos que restauram, redescobrem, recriam, redimensionam, transformam e atualizam relatos da história oficial, da ficcional e da realidade. Texto e contexto exprimem ironias e metáforas, do passado e do presente, em diferentes intensidades que diremos sonoras, porque propomos olhar a criação de Nélida como uma regência orquestral dessas relações. Por todo o romance há uma fragmentação temporal que decompõe o texto original, gerando versões que podem ser produtos novos e/ou releituras do enredo. $\mathrm{O}$ narrador cronista, por exemplo, discute com a personagem Álvaro tais movimentos:

Talvez me queiras submissa a histórias cujo sentido do real se concilie com fatias de uma realidade oficial, de modo que me seja fácil segui-las. Mas de que me serviriam estas vidas sólidas, com telhado e vigas mestras, que se deixam ligeiramente retocar e jamais se transfiguram. Encarregadas da obediência e da colheita, elas proíbem qualquer transgressão. Enganas-te muito Álvaro. Não pretendo cingir-me aos parceiros brandos, de calendário ocupado com festas previstas desde o nascimento até o cortejo da morte. (PIÑON, 1988, p. 17)

Nélida vai introduzindo, gradualmente, novos "instrumentos", intensificando o uso de uns e silenciando outros, alternando seus significados, redimensionando suas funções e intensidades. Comporta-se como uma maestrina que - na regência de uma ópera - conduzisse cuidadosamente cada instrumento musical, cada setor sonoro da orquestra e cada nota da partitura, de uma obra composta por outrem, mas tomada a si naquele momento. O "canto" de cada ator seria conduzido pelo interior e exterior dos seres representados e essa atuação, de cada um, traria ao palco os seus próprios elementos criativos, a sua bagagem cultural acrescida da técnica vocal.

A regência que propomos seria o trabalho da escritora, cumprindo uma etapa do que ela própria designa como destino - num trecho do seu discurso de posse na presidência da Academia Brasileira de Letras, proferido em 12 de dezembro de 1996 - e que ela reforça, ao longo da narrativa, no discurso de seus narradores. Citamos:

Guardo desde menina, irrestrita fidelidade ao destino da escritura. Apraz-me proclamar, sem pressa ou arrogância, que sou filha dos livros e da imaginação. E que, a despeito da eterna vigília que perturba o coração dos homens, confio nas atribuições e na soberania da arte. Na perenidade do escritor, aquele nostálgico rapsodo que teima em captar os ruídos dos estertores humanos. (PIÑON, 1996, grifos nossos)

Apalpo a vida. Auscultando-lhe a ruidosa exuberância, aprendi que nada exige a minha presença. Unicamente meu corpo narrador afina-se às próprias funções, e tece uma respiração ajustada a um sistema de ar mediante o qual componho notas musicais e espasmos. (PINON, 1988, p. 19, grifos nossos) 
A memória porém habita-me o corpo como um musgo agreste. Não devolve apenas o que me aquieta. Até prefere as reservas afetivas que justamente me sufocam. A elas tomo nos braços e, mediante o seu ímpeto, recupero subitamente Tebaldi [...].

Tantos anos já se passaram. O tempo caçou borboletas e o nosso afeto. Mas, quantos, dentre nós ainda estão vivos, devotam à vida a mesma paixão de outrora. E permitiram que o mais visível dos seus rostos fosse o pedaço do nosso medo. Não tenho respostas. A história interpõe-se entre o vulnerável $e$ o que não alcanço. Recordo, sim, haver pedido à cronista, apenas surgindo, que se cuidasse, não permitisse que a umidade lhe mofasse a alma. Ela, a quem estava eu atada por um fado comum, apenas prometeu-me que manteria constantemente seu solo assaltado pelas dúvidas, não lhe faltando razões de luta enquanto o humano fosse o objetivo. Mas, em que real medida aquela $A$ Força do Destino, de fusos horários e afetivos tão distantes, poderá ainda responder por um estágio a que falte talvez certo paladar de mel? (PIÑON, 1988, p. 47-48, grifos nossos)

Tomamos a apresentação de uma ópera ${ }^{1}$ como metáfora dessa construção literária por considerar que a sua estrutura narrativa e a presença do caráter paródico remetem a essa manifestação artística. $\mathrm{O}$ uso da intertextualidade com um espetáculo musical, que teve por base uma peça teatral, formaliza, em nossa análise, a possibilidade que aventamos. O parodiar está na (re)apresentação do enredo e das características das personagens sob novo ângulo, o das suas inconsistências, destituindo a dramaticidade da ópera de sua aparente e laudatória veracidade. Nélida faria assim uma releitura do drama utilizando fundamentalmente a comicidade ${ }^{2}$.

A ópera, a que vimos referindo, foi composta por Guiseppe Verdi ${ }^{3}$ em 1861, com libreto de Francesco Maria Piave ${ }^{4}$, tendo estreado no Teatro Imperial de São Petersburgo, em 10 novembro de 1862. La Forza Del Destino, em quatro atos, é baseada na peça Don Álvaro o la fuerza del sino, de 1835, escrita por Angel Pérez de Saavedra $^{5}$, Duque de Rivas, que fora o primeiro sucesso do Romantismo Espanhol. Nossa perspectiva da relação entre o texto teatral e a ópera é de uma espécie de paráfrase, no sentido de que as temáticas inscritas em ambos são semelhantes, a

\footnotetext{
${ }^{1}$ Conceituamos ópera como um "drama cantado com acompanhamento de orquestra ou intercalado com diálogos falados, ou com recitativo" de acordo com a definição de Ferreira (1977?).

${ }^{2}$ Ressaltamos que a conceituação de drama pressupõe a presença do trágico e do cômico e que este último elemento é de uso recorrente em todo o romance, ao que referiremos adiante.

${ }^{3}$ Giuseppe Fortunino Francesco Verdi (1813-1901), compositor de óperas do período romântico italiano considerado o maior compositor nacionalista da Itália. As óperas Rigoletto (1851), Il Trovatore (1853), La Traviata (1854) e Aida (1871) foram seus maiores sucessos e são, até hoje, as mais representadas. Tinha como diferencial uma grande dramaticidade nas composições e uma opção por intérpretes capazes de atuarem além de cantarem.

${ }^{4}$ Francesco Maria Piave (1810-1876), poeta e libretista de ópera, ardoroso nacionalista italiano, amigo de Verdi; autor do libreto La Forza del Destino.

${ }^{5}$ Angel Pérez de Saavedra y Ramirez de Baquedano, Duque de Rivas, (1791-1865), escritor, dramaturgo, poeta, pintor e político, autor da peça Don Álvaro o la fuerza del sino, primeiro sucesso do Romantismo Espanhol.
} 
dramaticidade foi mantida e os contextos, em que elas se inserem, podem ser vistos como um prolongamento, um movimento de retomada, acrescida de nova roupagem.

O romance promove a atualização tanto da história quanto do discurso, através do diálogo que narradores e personagens estabelecem entre as diferentes épocas e as diversas linguagens. Ao imbricar três gêneros de arte - teatro, ópera e romance - Nélida Piñon estabelece um espaço de recriação carnavalizada de tema, enredo e contexto, o que inserimos no sentido de "avesso", conforme proposto por Bakhtin:

\begin{abstract}
O carnaval é um espetáculo sem ribalta e sem divisão entre atores e expectadores. No carnaval todos são participantes ativos, todos participam da ação carnavalesca. Não se contempla e, em termos rigorosos, nem se representa o carnaval mas vive-se nele, e vive-se conforme as suas leis enquanto estas vigoram, ou seja, vive-se uma vida carnavalesca. Esta é uma vida desviada da sua ordem habitual, em certo sentido uma "vida às avessas", um "mundo invertido" ("monde á l'envers"). (2005, p. 122-123, grifos do autor)
\end{abstract}

A existência do "avesso" poderia ser entendida, no romance, como uma paráfrase, no sentido de tradução, ou como uma paródia, na consideração de um desenvolvimento crítico. Haveria uma metamorfose da peça teatral e/ou do argumento do libreto da ópera, dentro do que Bakhtin (2005, p. 123) designa como "cosmovisão carnavalesca". A presença da ironia e do humor permite múltiplas leituras, pelo contraste das diversas linguagens expressas na obra literária, de modo que o tempo histórico e o gênero se apresentam numa intersecção flexível, através de diferentes vocabulários e estilos. A amplitude desse contraste é especialmente significativa, na composição de Nélida, se acompanharmos a afirmativa de Bakhtin (2005, p. 142) de que "a linguagem de um gênero é concreta e histórica". Nesse sentido, encontramos, ainda, no autor:

[...] o carnaval, suas formas e símbolos e antes de tudo a própria cosmovisão carnavalesca, séculos a fio se entranharam em muitos gêneros literários, fundiram-se com todas as particularidades destes, formaram-nos e se tornaram algo inseparável deles. É como se o carnaval se transformasse em literatura, precisamente numa poderosa linha determinada de sua evolução. Transpostas para a linguagem da literatura, as formas carnavalescas se converteram em poderosos meios de interpretação artística da vida, numa linguagem especial cujas palavras e forma são dotadas de uma força excepcional de generalização simbólica, ou seja, de generalização em profundidade. Muitos aspectos essenciais, ou melhor, muitas camadas da vida, sobretudo as profundas, podem ser encontradas, conscientizadas e expressas somente por meio dessa linguagem. (2005, p. 158-159, grifos do autor) 
O distanciamento temporal é superado pela autora ao colocar Nélida - cronista de jornal - e Verdi, compositor, como personagens que dialogam com as que se constituem no passado. Destacamos aqui a ironia presente no fato de uma "cronista" ser alguém que fala de um presente instantâneo, que logo se torna passado, e ser a própria autora exímia executora desse gênero. Ela apresenta o encontro de Verdi com a cronista numa atualização atemporal o que também permite, ao leitor, posicionar-se diante de duas "versões" de uma mesma história, como identificamos nos recortes seguintes:

\begin{abstract}
Muito pois se teria a dizer de Preziosilla, se ela viesse a tomar vulto nesta história. Temo porém que seu papel aqui seja modesto e passageiro. Não ultrapassará cinco minutos de leitura. Mais me encantaria ceder-lhe, mas não posso. Me é mesmo difícil pô-la sob a minha custódia, quando lhe prometo vida tão breve. A culpa não é minha. Verdi exigiu-lhe a presença, sem me ceder explicações. Suspeito que na juventude chegou a tê-la no próprio leito, prometendo-lhe então a glória. E cumpriu a promessa. (PIÑON, 1988, p. 109)

Lamento comunicar aos leitores que Preziosilla, a cortesã amiga de Verdi, que tão amavelmente cercou-nos de cuidados, prepara-se para deixar-nos, já no próximo parágrafo. Tudo fiz para mantê-la em nossa companhia. Pensei até em convidá-la a visitar a Espanha, que não é tão longe assim. Certamente ela teria apreciado. Mas, submissa às injunções históricas, temi infringir disposições superiores à minha vontade. (PIÑON, 1988, p. 111)

Constrange-me, porém, a perda de personagem com quem tão pouco convivi. Resta-me a esperança de que, ao abandoná-la, permiti-lhe a felicidade. $\mathrm{O}$ direito de envelhecer na sua Itália renascentista, diariamente alimentando-se de uma pasta al succo que, para alcançar-lhe o prato, não hesitou em vencer mares exóticos. (PIÑON, 1988, p. 111-112)
\end{abstract}

Os movimentos que todas as personagens realizam, são tanto teatrais, quanto discussões críticas, pois elas circulam nos tempos idos, no presente da escritura e imaginam outras soluções e relações possíveis num pretenso futuro. Essa circulação de narradores e personagens propicia os movimentos orquestrais, em função da inexistência de fronteiras temporais fixas no enredo e da flexibilidade na forma da obra. Essa mobilidade permite a desconstrução para reconstruir, tanto da história quanto da própria criação literária. Exemplificamos:

Nélida segredou, deixe-me livre, já não lhe pedi antes, jovem Leonora? A sevilhana tinha consciência dos próprios encantos, desdobrava-os como a um lençol de linho. Mesmo apesar dos meus olhos compungidos, Nélida? Especialmente por eles. Está bem, sua cronista ingrata, te banirei para sempre, serás uma proscrita. Não quis dizer isto, Leonora, sabes bem que também não posso esquecê-los agora. Neste caso tire-me desta taberna, o irmão aí [Carlos, irmão de Leonora] está querendo matar-me. Não pode ser, Leonora, arrancas-me do Leblon justamente quando meus sentimentos florescem por aquela praia e bosque, apenas para indicar-te aquela porta, por onde passarás sem ele te ver, entretido que está na vingança? [...] Mas, como falaremos, agora que fujo, venci o portal, já estou na estrada começo a correr, 
que calor, para onde estamos indo muleiro? Deixa por minha conta, Leonora. Eu sou a tua sombra. (PIÑON, 1988, p. 37-38)

Sem se dar conta, há muito o abade a aguardava. Com a mesma ansiedade dos lares sevilhanos. Naqueles dias Leonora ultrapassara os limites do real possível, para ingressar no real imaginário, que era o sonho coletivo. E assumira o abade o papel de narrador, na cadeia dos relatos que tinham Leonora como protagonista. Cabendo-lhe pois confrontar a notícia oral, inadvertidamente chegada às suas mãos, com a realidade possível, trazida por Leonora. (PIÑON, 1988, p. 72)

O jogo que Nélida - autora - estabelece, ao longo do romance, desencadeia uma nova interpretação das personagens, que se autodefinem e se inter-relacionam em parâmetros de época, tanto a do período inicialmente teatralizado, quanto a da escritura do romance, um "gênero polissêmico e inquietante" como ela própria define (2008, p. 34). O leitor assume, nessa dialética, o direito de construir outros sentidos, entrando na obra com suas próprias analogias, de significados contemporâneos a ele, a qualquer tempo em que dela se aproprie. A cada nova apropriação um novo texto pode ser construído, através de outros universos discursivos o que, metaforicamente, é o desenrolar de um jogo com inúmeras partidas, cujos jogadores podem ser alternados e/ou substituídos ao longo do tempo.

A partir desse jogo, ocorre-nos a idéia de um espetáculo teatral, onde múltiplos papéis são encenados por um mesmo ator, que entra diversas vezes em cena, alternando seqüencial e/ou aleatoriamente suas personagens, ou, quando há alternância dos atores na interpretação de uma só personagem. O leitor seria, assim, um espectador que poderia assistir várias possibilidades de encenação de um mesmo papel, reconhecendo nesta diferentes instâncias discursivas através das diversas linguagens. Sobre essa relação de diversas vozes, nos fala Cristóvão Tezza, ao discorrer sobre conceitos básicos de Bakhtin: "no universo bakhtiniano nenhuma voz, jamais, fala sozinha. E não fala sozinha não porque estamos [...] mecanicamente influenciados pelos outros [...], mas porque a natureza da linguagem é inelutavelmente dupla" (1997, p. 221).

As personagens do romance discutem com a cronista que as acompanha na ficção o seu próprio destino, imprimindo no texto o seu processo de concepção e nascimento, reportado por Nélida em suas considerações sobre a criação literária:

A literatura [...] tem caprichos estéticos. Faculta ao autor culpar ou inocentar personagens, formular um veredicto moral nem sempre compatível com as leis dos homens, dar vazão à política do bem e do mal, como se a matéria humana tivesse a mesma procedência e composição. Permite que o mundo novelesco seja condescendente em seus ajuizamentos e tenda a absolver os pecadores, a dispensar hierarquias em prol dos laços humanos. (2008, p. 35) 
[...] a conquista da vida, por parte do personagem, talvez ocorra quando ele atende ao nome que é pela primeira vez pronunciado. Ou quando, agindo de forma soberana, deixa entrever, no seu bojo, uma multidão de seres de quem herdou características relevantes. Um personagem que, reagindo ao the enunciarem a existência, quer negar, como ato preliminar de rebeldia, o destino que o autor está na iminência de lhe conferir. Ajustado à batalha que se trava entre criatura e criador. (2008, p. 37)

O leitor, por sua vez, instaura a sua própria "versão" dessas personagens, em consonância com os seus próprios valores, também passíveis de revisão e atualização no decorrer dessas discussões.

Cada ser ficcional designado como personagem dá vazão à multiplicidade, isto é, a representação de tantos seres quantos a realidade possa abarcar, numa "reconstituição" permanente, tal como propõe a romancista ao dizer que "quem dá substância à narrativa não é o personagem nomeado pelo autor para existir, mas o arquétipo que, produzido por todos, coordena, à sombra ou ao sol, os disparates do estatuto humano" (PIÑON, 2008, p. 211). Ao fazerem um movimento de interiorização, essas criaturas literárias convidam a "platéia", o "ouvinte" e o "leitor" a fazerem o mesmo percurso, mesclando assim suas diversas genealogias. Citamos o exemplo:

Onde pensa que vai, seu vagabundo carioca?

Eu, [Álvaro] vagabundo! O Marquês equivoca-se. Pertenço à Invencível Armada, ou melhor, ao que sobrou dela nos portos de nosso litoral. Selou-me a sorte de ser militar, de pequena estirpe, é verdade, mas digna e bem capaz de alcançar o generalato, bastando que aconteçam cinco guerras seguidas. Meu futuro depende da ambição e da susceptibilidade do rei. Mas confio que o nosso soberano não há de aquietar-se, ou aceitar insultos sem pensar em revidá-los imediatamente. (Por favor, Nélida, corta logo esse papo, não agüento mais cantar o velho. Ele parece irredutível. Nem pisca o olho. Eu diria que mal respira. Tudo indica que chegaremos às vias de fato. E eu estou noutra. Não quero briga, só quero a garota, o que não é pedir muito. Deixa o Verdi na mão e me salva depressa.). (PIÑON, 1988, p. 26)

Os discursos presentes nas diferentes épocas são questionados através da carnavalização da história, que parte dos elementos trágicos - claramente institucionalizados - revestindo-os do riso, numa atualização que amplia os sentidos, embora mantenha cada personagem preso à metáfora do destino. A palavra reveste-se, no romance, de uma plasticidade e mobilidade capaz de compor imagens distanciadas cronologicamente, embora relacionadas entre si. Imagens essas que são construídas pelo leitor, ao sobrepor o seu texto ao do autor que, por sua vez, já o fez ao recorrer à paródia, dando vazão às diversas vozes implícitas no romance. Associamos aqui as colocações de Cristóvão Tezza, quando analisa as proposições de Bakhtin: 
O outro conservará sempre, na linguagem romanesca, o seu grau de autonomia, que pode ser imenso, como nos concertos polifônicos de Dostoiévski, ou mínimo, como nas sátiras mais demolidoras - mas em qualquer caso a voz do outro, refratada pelo olhar do autor-criador, será reconhecível, estará presente, respirará em cada linha do texto. Se a autonomia do outro desaparece, desaparece, com ela, a linguagem romanesca. (TEZZA, 1997, p. 225, grifos do autor)

O enredo melodramático que baseia a paródia se presta a essa formatação e permite a apresentação de vários pontos de vista possibilitando a presença da crítica, através de uma espécie de caricatura, que pode ser executada pelos narradores ou pelas personagens, que pode ou não ser endossada pelo leitor, reiteradamente convidado a opinar:

Ela mesma [Leonora] já não existia. A confirmação de sua existência serviria apenas para diminuir o impacto e sofreguidão da narrativa que ela personalizava. [...] E saberia que protagonizar um fato era irrelevante, real importância possui quem inventa a história, dá-lhe corpo para que circule, transforma-a no relato há muito aguardado pela coletividade, para também narrar. (PIÑON, 1988, p. 72)

Não adianta repreendê-la. Não quero você entre soldados, não fica bem. O que diriam de minha mulher, de uma nobre sevilhana? Há que cuidar das aparências, Leonora. Zangada, tomaria da água e do sabão, lavo-me lá fora, não suporto suas reclamações. Eu lhe diria, confessa que me ama e enfrentou os perigos deste mundo em nome desta paixão? Me beijaria, para não causar distúrbios. Talvez planejasse fugir na semana seguinte, pelo prazer de repetir as mesmas emoções da última cavalgada noturna. Mas, com que outro cavalheiro teria seguido, deixando-me à mercê do desgosto? (PIÑON, 1988, p. 76)

Nélida reflete sobre o ato de criar, sobre a forma, a recepção da obra literária e a sua função. Abre para a percepção da posição social do próprio escritor, quando permite aos narradores analisarem os papéis sociais na Europa dos séculos XVIII e XIX tempos tematizados na peça e revisitados na ópera - na sua versão. O mesmo ocorre com as personagens que se apresentam e reapresentam alternando diferentes “roupagens". Nessa tensão, entre o que está institucionalizado e o que é possibilidade a ser realizada, é gerado o ato de criar e recriar diversas histórias da História:

Somos, o abade e eu, simples mediadores. Escrevendo, ou à escuta, nos apertados corredores das fechaduras. A recolher material disperso, colando a alguns com simetria. De outros preservando-lhes o aspecto de feira, com eles desde o nascimento, na manjedoura. Este é um ofício necessário. Não nos tivéssemos dedicado a ele, e os elos humanos por si se desfariam, perderia a linguagem o poder de combinar o circunscrito a ela com o que se faz em seu nome, a invenção com o percurso biográfico. Sem o nosso esforço, se ignoraria que atrás da história existe outra, uma outra ainda existe atrás, assim sucessivamente, até o começo do mundo.

Anuário de Literatura, ISSNe: 2175-7917, vol. 14, n. 1, 2009, p.34 
Uma tarefa fundamental é preservar a história humana. Quer através de novos subsídios, quer torcendo-lhe os fatos, fiéis sempre a inesgotável cadeia narrativa, que jamais se rompe. Para que ao registrar um fato, ao interromper um acontecimento com minha própria versão, esteja eu sempre a sonhar com vozes humanas, cobrando-lhes calor e vísceras. (PIÑN, 1988, p. 72-73)

Ao longo de toda a narrativa, ocorrem situações de fragmentação do indivíduo nos diferentes tempos, através de questionamentos do mundo exterior e dos seus aspectos intimistas. Essas ocorrências são protagonizadas por narradores, personagens e pela própria autora que se presencializa, a nosso ver, quando relata fatos verdadeiros ocorridos em sua vida. Identificamos nisso um processo de desconstrução para constituição do novo, característico do que se discute, no presente, sob o prefixo de pós, nesse caso da pós-modernidade. O antigo e o novo produzem, como propõe Homi Bhabha, uma busca constante pois, "neste fin de siècle [século XX], encontramo-nos no momento de trânsito em que o espaço e tempo se cruzam para produzir figuras complexas de diferença e identidade, passado e presente, interior e exterior, inclusão e exclusão.” (2003, p. 19). Relata a autora:

\begin{abstract}
Com quatorze anos, Tebaldi bateu-me à porta. Quiseram a emoção e a minha história que fosse pela $A$ Força do Destino. Em vez da Traviata, ou mesmo Tosca. Hoje, tantos anos depois eu não saberia explicar a preferência, um rumo que se deixou simplesmente comandar pelo amor. Sei que tinha o corpo de agora, e ainda certa vocação para as lágrimas. E não que as vertesse pelos fantasmas e o mel perdido, mas porque a vida exaltava-me.

Àquela época, éramos todos ávidos. Por tal motivo, decidimos seccionar o Municipal em dois palcos hipotéticos, de modo que ambos abrigassem o trágico amor de Callas, e os doces sentimentos de Tebaldi em separado. Sem dor para nós. Diante da nossa fúria juvenil, as duas vertentes opunham-se radicalmente. (PIÑON, 1988, p. 45)
\end{abstract}

A citação anterior é precisa quanto ao ocorrido, no que concerne à época, que identificamos como 1951, quando Renata Tebaldi ${ }^{6}$ e Maria Callas ${ }^{7}$ estiveram no Rio de Janeiro numa temporada no Theatro Municipal. Ambas eram intérpretes de Floria da Tosca de Puccini, de Violeta de La Traviata e Leonora de La Fuerza del Destino, estas de Verdi. Callas era considerada a soprano mais emocional do canto lírico, passional

\footnotetext{
${ }^{6}$ Renata Tebaldi (1922-2004), cantora lírica italiana, considerada a segunda melhor soprano de sua época; conhecida pela maestria na interpretação das obras de Verdi, entre as quais se destaca a personagem Leonora de La Fuerza del Destino.

${ }^{7}$ Maria Callas, nome artístico de Cecília Sofia Anna Maria Calogeropoulous, (1923-1977), americana de origem e formação musical grega, considerada a melhor soprano do seu tempo; intérprete de grandes papéis, destacando Leonora de La Fuerza del Destino. Tinha como diferencial a dramaticidade emocional das interpretações.
} 
segundo alguns, e Tebaldi, tida como a segunda melhor soprano, era mais clássica.

$\mathrm{Na}$ ocasião irrompeu um desentendimento entre ambas, que perdurou até $1968 \mathrm{e}$ provocou cisões e discussões acirradas, além de muita publicidade. Nélida, a escritora, se apropria de acontecimentos da vida real e os insere entre aqueles que o seu romance conta, instalando-se, desse modo, no discurso dos seus narradores. As suas colocações, sobre a paixão despertada pela ópera, são um paralelo entre o que ocorrera no seu tempo histórico e o que ela apresenta na dramaticidade sobre a qual estabelece a paródia atual.

Encontramos, nesse momento do romance, o manuseio da memória de Nélida Piñon que fala sobre um passado vivido, na intensidade dos significados da ocasião, revisita-os ao tempo da escritura do romance, e imprime essas marcações no texto. Diz ela: "A memória [...] habita-me o corpo como um musgo agreste. Não devolve apenas o que me aquieta. Até prefere as reservas afetivas que justamente me sufocam.” (PIÑON, 1988, p. 47) Entendemos esse diálogo entre os dois contextos como uma forma de "recriação", ao que a romancista designa como "materialização":

Sou, naturalmente, o que penso, mas melhor me materializo ao admitir ser o que escrevo. A escritura é o discurso visível da minha alma. E, embora seja ela capenga, sujeita-se ao crivo exegético do outro, não alberga segredos que alijam a sensibilidade universal. Ainda que a arte, advinda do esforço humano, simule ser uma entidade enigmática que se expressa mediante espessa simbologia. (2008, p. 205)

Ocorreria assim uma possibilidade de ultrapassar as fronteiras entre passado e presente datados, numa condição de atualização da escrita e de recuperação das emoções, dos significados profundos do ser humano. Identificamos, na escritura de Nélida, uma busca de "revalidação" da função do escritor que, segundo suas palavras, "ao oferecer à sociedade um projeto narrativo [...] faz coincidir a escritura com a poética do cotidiano. Torna a vida tão especulativa quanto a arte.” (2008, p. 41). Sua elaboração extrapola o registro dos elementos fundados na tradição, acrescendo-lhes a consideração de valores superáveis ou regeneráveis, o que identificamos em trechos como:

Não foi fácil eleger entre elas [Maria Callas e Renata Tebaldi]. O coração dividia-se para eu não segui-lo. Já então clamando por sangue vivo, sua viva mancha na parede. Embora amasse cristais. A tragédia de Callas localizavase precisamente em sua voz, um aparelho que purgava a própria vida com sofrimento. Nela os sentimentos eram gregos, com o leve retoque de dois mil anos. E porque solidarizava-me com aquele esqueleto de som e urgência vocal, ousava sob sua inspiração contestar deuses, solicitar oposições e sempre contrários. Também queria a alegria de viver.

Foi Tebaldi quem me ensinou a rir e chorar ao mesmo tempo. Venceu unicamente porque fabricava liturgias num picadeiro. Logo para mim que aprendia a amar com as cordas finas do coração. A projetar-me ainda à cova 
dos leões, de jubas adornadas, experimentando ser devorada. Queria coçarlhes a garganta, para que pedaço meu não permanecesse muito tempo no estômago, a dilatar-lhe as tripas. Desde o início, eu valorizava os sucessivos combates e a claridade. Tudo me pretextava a luta. $\mathrm{O}$ amor, o arrebato, a atenção que nos dispensavam os heróis do palco. Naquela terra do imaginário, simplesmente prolongávamos emoções iniciadas há séculos, sucedíamos a um passado anterior a nós. (PIÑON, 1988, p. 45-46)

Haveria desse modo, o refazimento de sentidos do contexto original que estariam registrados no texto numa amplitude tanto ilimitada quanto interior. Colocar-se na narrativa faria parte do processo autoral de Nélida, da sua linguagem criadora, que dividiria com o leitor não só o texto produzido, mas os contextos em que a temática proposta transita incluindo, nessa "parceria", as memórias pessoais. A ficção estaria, assim, permanentemente impregnada pela dúvida, pelo questionamento e pela mobilidade, tal como encontramos no seguinte trecho:

\footnotetext{
Tantos anos já se passaram [período entre 1951 e 1977]. O tempo caçou borboletas e o nosso afeto. Mas, quantos, dentre nós, ainda estão vivos, devotam à vida a mesma paixão de outrora. E permitiram que o mais visível dos seus rostos fosse o pedaço maior do nosso medo. Não tenho respostas. A história interpõe-se entre o vulnerável e o que eu não alcanço. Recordo, sim, haver pedido à cronista, apenas surgindo, que se cuidasse, não permitisse que a umidade lhe mofasse a alma. Ela, a quem estava eu atada por um fado comum, apenas prometeu que manteria constantemente seu solo assaltado pelas dúvidas, não lhe faltando razões de luta enquanto o humano fosse o objetivo. Mas, que real medida aquela $A$ Força do Destino, de fusos horários e afetivos tão distantes, poderá ainda responder por um estágio a que falte talvez certo paladar de mel? (PIÑON, 1988, p. 47-48)
}

Ao tomarmos, na atualidade, o livro de Nélida Piñon encontramos um Giuseppe Verdi que, ao seu tempo, compôs refletindo os discursos sociais de época - semelhante ao Duque de Rivas com a escritura de sua peça espanhola - e uma autora que mobiliza os discursos presentes em sua memória e na vivência à época da elaboração do romance. Há um cruzamento de sentidos que nos leva a propor que, além de uma intertextualidade - considerada como uma sobreposição de textos - possamos considerar uma formação de "sub-enredos", disponíveis a narradores, personagens e leitores.

Assumir o amor pela ópera e pela palavra, datando e localizando um evento verídico, como faz a autora, imprime no romance uma marcação realista, de cunho intimista, pois é a escritora brasileira, Nélida Piñon, do século XX, que se registra na narrativa. É a afirmação do uso do espaço memorial do autor na obra de ficção, possibilidade que ela própria coloca, ao falar de si. 
A verdade é que, perdida neste mar de sargaços, há muitos anos iniciei a viagem que me traz hoje a este salão nobre. Uma viagem feita, entre outros tropeços, de vontade individual, de coincidências coletivas, de acasos que certos deuses, afetados pela passagem do tempo, incumbem-se de decifrar. Feita também do desejo que me levou a explorar escaninhos, a acercar-me das caixas lacradas, onde o mistério humano, sempre precariamente encarnado, depositou, à minha revelia, certos manuscritos. (PIÑON, 1996)

A cultura está, entre os homens, para semear a discórdia, o fluxo das emoções desmedidas, mas reveladoras. Habita o homem e extrai-lhe o avesso, suas crateras, o rosto frontal. Não emudece, não recua, não se esconde. Tece simplesmente as intrigas que enlaçam os homens irremediavelmente, e que facilitam, embora de modo fugaz, o mútuo reconhecimento. (PIÑON, 1996)

Como escritora, origino-me da fantasia do meu tempo e diariamente regresso ao seu chão. No curso desta travessia, imolo-me a serviço do advento da fabulação. Assim, se escrevo com modéstia, invento com exaltação, o estado ígneo respondendo pela febre que necessito. Em qualquer circunstância, socorro-me da palavra, à véspera de ser linguagem. Nada sou sem ela. Seu prestígio redimensiona o que julgo ser a realidade. Minha apreensão do mundo expressa-se segundo seus favores. E apesar do verbo subscrever intenções, sobressaltos, musicalidade, igualmente fomenta a desordem com que se cumpre, aliás, a rota da invenção. (PIÑON, 2003, p. 205)

$\mathrm{O}$ enredo permanece aberto, dinamizado pela presença de elementos como a dúvida, a interrogação, o rompimento e a atualização, o que nos leva a situar o romance como uma "representação", suscetível de novos e constantes movimentos. Estabelecemos, aqui, uma analogia com sucessivas (re)apresentações de uma peça teatral. Acreditamos que o distanciamento temporal da elaboração original oportuniza novos preenchimentos do caráter paródico proposto, num jogo que permite não só a deformação do enredo, como a fragmentação dos personagens, que transitam em épocas distintas, compondo seus papéis de acordo com as possibilidades e necessidades dos respectivos contextos.

Nossa leitura não identifica a ironia apenas como uma marcação do texto inspirador, mas, também, como uma ampliação para o contexto de onde se origina o escrito paródico. Com a livre circulação dos seres da ficção se movimentem entre o real e o imaginário e em tempos cronológicos distintos, ocorre uma diluição da fronteira temporal entre os contextos, permitindo que o texto atual possa ser uma referência de transformação e não, meramente, de deformação do pré-existente. A retomada do enredo funciona, nessa perspectiva, como uma reconstrução dos símbolos e representações que compõem a cultura nacional onde são produzidos e, sob essa ótica, diríamos que esse processo é parte da maestria da autora, na regência a que aludimos.

As personagens, exemplarmente Leonora e Álvaro, do texto de Saavedra e do libreto de Piave são, em nossa proposição, alegorias do homem de suas respectivas 
épocas, que o romance de Nélida une e contrasta, numa dinâmica do que hoje chamamos de crise de identidade. Acompanhamos em nossa reflexão as colocações de Stuart Hall, quando este afirma que:

Um tipo diferente de mudança estrutural está transformando as sociedades modernas no final do século XX. Isso está fragmentando as paisagens culturais de classe, gênero, sexualidade, etnia, raça e nacionalidade, que, no passado, nos tinham fornecido sólidas localizações como indivíduos sociais. Estas transformações estão também mudando nossas identidades pessoais, abalando a idéia que temos de nós próprios como sujeitos integrados. Esta perda de um "sentido de si" estável é chamada, algumas vezes, de deslocamento ou descentração do sujeito. Esse duplo deslocamento descentração dos indivíduos tanto de seu lugar no mundo social e cultural quanto de si mesmos - constitui uma "crise de identidade" para o indivíduo. (2006, p. 9)

Em 1978, ano da publicação d'A Força do Destino, Flávio Loureiro Chaves apresenta, no caderno literário do Correio do Povo, de Porto Alegre, alguns textos refletindo sobre ficção incluindo esse romance, sobre o qual ele nos diz: "Nas malhas d'A Força do Destino revela-se [...] uma consciência da historicidade do texto literário e da função do escritor." (1978, p. 106, grifo do autor) Concordamos com tal afirmativa e estabelecemos uma associação com as palavras de Nélida no seu discurso de posse na presidência da Academia brasileira de Letras:

Como todos os ilustres confrades, também cheguei à Academia Brasileira de Letras trazida pelo instinto da arte. Esta arte que, cúmplice do desejo coletivo, mobiliza cada ser humano. E revestida da condição de escritora para melhor combinar a arte literária com a apologia da consciência individual e coletiva. São os reclamos humanos que concedem à literatura a proteção do saber, o arrimo da compaixão e da piedade.

Assim, onde esteja, em especial desta tribuna, confesso acreditar na aventura humana, no direito que nos assiste de exaltar, através da narrativa, esta enigmática viagem que encetamos todos em direção ao centro de nós mesmos. Na busca permanente da residência dos nossos alentos.

Uma narrativa que se ampara, e apura-se, no ato, ou no ofício de revelar os homens e a sociedade em que habitamos. Delicado e incerto ofício que conta apenas com a palavra, arma que fere, decepciona, exalta, pensa, surpreende - com a palavra, repito, para iluminar os desvãos da realidade. Graças à palavra, contudo, costuramos os atos humanos e acreditamos na força restauradora do espírito, tão presentes, e sempre reabilitados, nesta Casa de Machado de Assis. (PIÑON, 1996, grifos nossos)

\section{Refletindo sobre o ato narrativo estabelecido pela autora, Chaves coloca que:}

Desmantelar a ópera de Verdi para narrar A Força do Destino é um gesto de irreverência; mas também é, sobretudo, um ato de recuperação, de preservação da humanidade, porque atrás da história congelada existe subterraneamente uma outra: a história que Nélida Piñon fará nascer. (1978, p. 107) 
Propomos que a "outra história" a que o autor se refere é o elemento de interpretação que caberia ao regente da ópera, que partiria da composição pronta - a "história congelada" - para fazer surgir a sua, com novas possibilidades de entendimento. A "maestrina" Nélida se posicionaria também como um "ator" e, paralelamente, como um autor elaborando versões do argumento inicial.

Chaves nos fala também sobre uma "renúncia a qualquer atitude de onisciência" (1978, p.107) de Nélida o que associamos à mobilidade temporal que encontramos na obra. Nessa análise, destacamos ainda a idéia do avesso como ligação entre a ópera e o romance, que traduziria a idéia da criação como um jogo, ao que já fizemos referência. Diz o autor:

A narradora sabe que o texto sobre o qual trabalha the foi legado pela tradição como um monumento sacralizado desde sempre; por isto, é preciso relê-lo e reescrevê-lo; e, mais do que isto, é necessário deixar à mostra o ridículo de coisas tão sérias como... uma ópera de Verdi.

O desmantelamento da história conhecida é, assim, o processo de criação de um novo texto; o argumento de Verdi terá de ser revirado pelo avesso enquanto surge a narrativa de Nélida Piñon; destróem-se os clichês para que possam nascer as personagens. (1978, p. 106, grifos do autor)

Acompanhando ainda as considerações de Chaves, encontramos a de que Nélida apresentaria no romance uma atitude crítica em relação ao fazer literário, o que tornaria possível diferentes imbricamentos dos discursos presentes, distanciando-os de meras afirmações e/ou conclusões definitivas. De acordo com ele: "Contar os fatos é tarefa da cronista e implica recuperá-los do anonimato para inseri-los num universo caleidoscópico, plenamente humano [...]” (1978, p.107). Associamo-nos ao que diz o autor e exemplificamos tal possibilidade em dois trechos do romance:

Nem sei como teu pai, com fama de caçador de lobos, ainda não apareceu.

Não sabes então? Porque está escrito que o pai não virá para impedir a nossa fuga. Não creio, Leonora, é bem capaz dele aparecer só para dar continuidade à nossa história. E que história, se o nosso enredo justamente prescreve a fuga, silenciosa e moderada, com os ingredientes de um futuro feliz. Que graça haveria do pai nos surpreender? Presta atenção, Leonora, se o velho não aparece, como levaremos a nossa história adiante? De que material Nélida vai dispor para registrar em seus anais as nossas vidas? Admita, por favor, que não somos tão interessantes assim, o que a vida nos desfalcou não deu para nos aperfeiçoar. Afinal, não somos os primeiros a contrariar as determinações paternas e, enquanto não venha a emancipação feminina, não seremos os últimos a fugir. E não será a Nélida, macaca velha (o que é macaca velha/boba, expressão que se vai usar em duzentos anos, é só esperar para ver, não sabe você que a língua é um fenômeno da moda, corresponde a uma saia, um gorro, um leque, o modelo de uma carruagem?), que há de preocupar-se conosco, a menos, é claro, que lhe cedamos diariamente material de engenho, que constrói açúcar e os bolos arquitetônicos. (PIÑON, 1988, p. 10) 
Perdoem-me, leitores, se o meu nome ganha relevância na discussão ora presente. Posso assegurar-lhes que não havia autorizado Álvaro a denunciar uma presença que fatalmente provocaria atritos e suspeitas. Não cheguei também a proibir-lhe o meu nome. Pensei apenas que, perdido Álvaro por tanto amor, chegasse a esquecer-me. Vejo agora o quanto me equivoquei. (PIÑON, 1988, p. 11)

Viemos falando até aqui de desconstrução, reconstrução, atualização, restauração, divisão, e outros movimentos que fazem parte do fazer literário de Nélida Piñon n'A Força do Destino. Na leitura que propusemos ao início, tais movimentos resultam da maestria na regência da obra, cuja musicalidade e teatralidade são executadas por narradores, personagens, temporalidades, memórias, linguagens, contextos, histórias e História. A partitura que a maestrina rege é, em nossa metáfora, a obra de Verdi, e a sua batuta - seu instrumento de comunicação de sentidos - é a língua que ela movimenta com o manejo preciso das palavras, num preenchimento intencional de sentidos, sentimentos e emoções.

Ao reger sons, atos e destinos, Nélida executa movimentos amplos, abertos aos dizeres assumidos por cada um dos elementos, que são os donos das palavras, com as quais atravessam os tempos e rompem as interpretações tradicionais. A "cronista" assim nos fala:

Unicamente por minhas mãos ingressariam ambos [Leonora e Álvaro] na língua portuguesa, que é, como expliquei a Álvaro, um feudo forte e lírico ao mesmo tempo. Um barco que até hoje singra generoso o Atlântico, ora consolando Portugal, ora perturbando o Brasil. E porque esta língua tem vocação marítima, entende bem os impropérios do vento, mais que qualquer outra se deixa levar pelos sentimentos. [...] Nestas horas, como de propósito, a língua estimula os lamentos africanos, que lhe foram incorporados nos últimos quinhentos anos brasileiros. Com eles ela ganhou força e ardência. Ficou uma língua morena. (PIÑON, 1988, p. 13-14)

[...] nenhuma palavra me chega sem antes conhecer o cativeiro, de que só a liberto para convertê-la num elemento de contradição e despeito verbal. Obrigada a uma avidez que não me dá folga e envelhece-me oitenta anos às três da manhã. Como se fosse eu um reservatório de água onde bóiam frases e cloro que diariamente resgato do naufrágio. (PIÑN, 1988, p. 15-16)

Situamos no romance de Nélida a polifonia proposta por Bakhtin, quando as palavras nos chegam audíveis em várias consciências, que se manifestam em tempos e cenários diversos - no caso, locais geográficos - instaurando diferentes manifestações. Tomamos a exemplaridade dos heróis do argumento de Saavedra, revistos por Verdi e retomados por Nélida - Leonora e Álvaro - para ler os discursos propostos por Bakhtin, ao analisar a obra de Dostoiévski: "O herói dostoievskiano não é apenas um discurso sobre si mesmo e sobre seu ambiente imediato, mas também um discurso sobre o mundo: ele não é apenas um ser consciente, é um ideólogo.” (2005, p. 77). 
Propomos que o "discurso" que os heróis nos trazem ultrapassa - na paródia estabelecida - o individual e as discussões que eles promovem fundem o "discurso sobre o mundo com o discurso confessional sobre si mesmo" (BAKHTIN, 2005, p. 77). Suas vozes e discursos circulariam, então, pelos tempos diversos, oportunizando ao leitor elaborar imagens e construir sentidos atuais sobre o que foi discutido. Haveria, desse modo, a "fusão artística" que Bahktin (2005, p. 77) identifica em Dostoievski, isto é, "da vida do indivíduo com a visão de mundo, da mais íntima vivência com a idéia".

Os heróis n'A Força do Destino ultrapassam a si mesmos assumindo novas ideologias a cada retomada da fábula, vivenciam realidades superadas e se disponibilizam para as futuras, enquanto a cronista acompanha esses movimentos e ultrapassa o relato, ao se permitir discutir e refletir o próprio fazer literário. Tomamos como exemplo um trecho em que Álvaro e a Nélida - cronista - discutem a existência deste:

\begin{abstract}
Acaso insinuas que te devo gratidão, Nélida? Existo apenas porque te dedicas a descrever-me e, graças a teu empenho, ganho existência? Mesmo nas Índias, não havia sonhado que uma escriba, tomando-me pela mão, me cingisse a uma história com corpo verbal autônomo, em que ganhasse meu rosto imagens decididas exclusivamente por ela, só para embelezar-me. Jamais aspirei ser protagonista de uma história onde minha amada intervirá com apartes falsos, ou com a expressão de alguns de seus sentimentos. Agora, porém, que sou o texto, como saber se te decidiste ficar com a parte que nada tem de mim, mas pela qual unicamente me asseguras um perfil de medalha, de que me orgulhe, e não mais prescinda. E como se agradece a quem nos narra, minha cara Nélida? (PIÑON, 1988, p. 80-81)
\end{abstract}

Ao recontar os acontecimentos do melodrama, através da paródia, a autora usa a força da língua para fragmentar o discurso institucionalizado, cedendo a palavra aos seres ficcionais para que a devolvam ao seu texto, carregada de novos sentidos, como entendemos na colocação de sua cronista-narradora:

Esta língua portuguesa, Álvaro, quer-se fazer ouvir para sempre. De cada palavra demanda uso e volúpias novas. Sem se importar com o pedaço do corpo de que abdicamos para preservá-la. Ah, Leonora, por minhas mãos, e por elas apenas, esta língua recolherá atos, palavras, ações, para devolvê-los refletidos e massacrados. Por minhas mãos, ainda, Álvaro, eu os introduzirei definitivamente a uma língua que registra a vida de modo a que se cancele a inocência para sempre. (PIÑON, 1988, p. 15)

A palavra retorna renovada ao texto e a língua portuguesa assume os destinos das personagens de Saavedra e Verdi, num espetáculo de caráter universal, refletindo tantas possibilidades quantas nós, "espectadores-leitores” possamos criar.

Finalizamos nossas considerações afirmando que, n'A Força do Destino, Nélida Piñon rege uma ópera - sua paródia - estabelecendo sobre uma "realidade modelada" (HUTCHEON, 1989, p. 67) a sua maestria no ato de "criar/re-criar" utilizando, para tal, 
um "figurino" crítico e uma "afinação" de ironia. A partitura, isto é, o discurso musicado e teatralizado, é retomado dialogicamente pela autora que re-compõe o espetáculo em um novo tempo, deixando ao "espectador-leitor" a possibilidade de participar de cada nova apresentação, aplaudindo - ou não - os Álvaros e as Leonoras que se apresentam no palco. O romance é o "filtro mágico" que Nélida maneja ao fazer da literatura a arte que "nada mais é que uma singela tentativa de esclarecer nossa presença no mundo" (PIÑON, 2008, p. 39).

\section{Referências}

BHABHA, Homi K. O Local da Cultura. Tradução de Myriam Ávila, Eliana Lourenço de Lima Reis e Gláucia Renate Gonçalves. Belo Horizonte: Ed. UFMG, 1998.

BAKHTIN, Mikhail. Problemas da Poética de Dostoiévski. Tradução de Paulo Bezerra. Rio de Janeiro: Forense Universitária, 2005.

CHAVES, Flávio Loureiro. O Brinquedo Absurdo. São Paulo: Polis, 1978.

FERREIRA, Aurélio Buarque de Holanda. Novo dicionário Aurélio da língua portuguesa. Rio de Janeiro: Imago, [1997?].

HALL, Stuart. A Identidade Cultural na Pós-modernidade. 11 ed. Tradução de Tomaz Tadeu da Silva e Guacira Lopes Louro. Rio de Janeiro: DP\&A, 2006.

HUTCHEON, Linda.Uma Teoria da Paródia. Tradução de Teresa Louro Pérez. Lisboa: Edições 70, 1989.

PIÑON, Nélida. A Força do Destino. Rio de Janeiro: Francisco Alves, 1988.

__. Aprendiz de Homero. Rio de Janeiro: Record, 2008.

_. Discurso de Posse na Presidência da ABL: Memória da viagem. ACADEMIA BRASILEIRA DE LETRAS, Rio de Janeiro, 1210 1996. Disponível em: http://www.academia.org.br/abl/cgi/cgilua.exe/sys/start.htm?infoid=8319\&sid=290 . Acesso em: 16 fev 2009.

SAAVEDRA, Angel Pérez de. Don Álvaro o la fuerza del sino. Madrid: Editorial Espasa-Calpe, 1975.

TEZZA, Cristovão. A construção das vozes no romance. In: BRAIT, Beth (Org). Bakhtin, dialogismo e construção do sentido. Campinas: UNICAMP, 1997.

VERDI, Giuseppe. La Forza del Destino. Hamburg: Polydor International GmbH, 1987. 